\title{
PENANAMAN NILAI-NILAI TASAWUF DALAM KELUARGA
}

\author{
St. Rahmah
}

UIN Antasari Banjarmasin

\begin{abstract}
Family is a small community in society. Every Muslim is required to live in order to live the demands of Islamic teachings. The family is the most important unit for the development process of the ummah. a good personality is formed from a family that instills good manners.

The concept of family in Islam is quite clear even Islam is very priority of individual and family coaching. Because the family is a good prerequisite for a nation and Country, especially if all families follow the guidelines submitted religion, in addition the family is also the closest environment with children, since children are born, in this family the children will have much experience to grow and developing for the future.

Inside the family parents can give examples of behaviors that will be imitated by children, because in the family is the most effective place to membelajarkan value of religion to the child.

The role of parents in the family as guides, caregivers, teachers, mentors, and example in the family. Parents are very big role in inculcating the values of Sufism as the foundation of his children, With the inculcation of the values of mysticism by parents, it is expected that in the next stage of development the child will be able to distinguish good bad, right wrong, so that children can apply it in everyday life.
\end{abstract}

Keywords: the values of Sufism, family, children

\section{Pendahuluan}

Keluarga merupakan sebuah unit sosial terkecil dalam masyarakat mempunyai peranan yang sangat besar dalam mempengaruhi kehidupan dan perilaku seorang anak. Kedudukan dan fungsi keluarga dalam kehidupan manusia bersifat fundamental karena pada hakekatnya keluarga merupakan wadah pembentukan watak dan akhlak.

Keluarga sebagai lembaga terkecil dalam masyarkat memegang peranan yang sangat luas dalam membina kehidupan dan kepribadian sosial anak. Sesungguhnya dapat 
dikatakan bahwa keluarga adalah tahap pertama lembaga-lembaga penting sosial dan dalam tingkat yang sangat tinggi; ia berkaitan erat dengan peradaban, transformasi warisan, dan pertumbuhan serta perkembangan umat manusia. Secara keseluruhan, semua tradisi, keyakinan sopan santun, sifat-sifat individu dan sosial, ditransfer lewat keluarga kepada generasi-generasi berikutnya.

Keluarga merupakan denyut nadi kehidupan yang dinamis dan termasuk salah satu pranata yang secara kontributif mempunyai andil besar dalam pembentukan, penanaman, pertumbuhan, dan pengembangan pendidikan pada anak, karena keluarga dibangun melalui hubungan-hubungan kemanusiaan yang akrab dan harmonis serta lahir dan tumbuhnya gejala sosial serta pendidikan di lingkungan pergaulan keluarga, oleh karena itu sebagai pranata sosial pertama dan utama, mempunyai arti paling strategis dalam mengisi dan membekali religious values (nilainilai keagamaan) yang dibutuhkan anggotanya dalam mencari makna kehidupan.

\section{Pembahasan}

\section{Keluarga Dalam Islam}

Dalam Kamus Besar Bahasa Indonesia disebutkan bahwa keluarga adalah terdiri dari ibu bapak dengan anak-anaknya. (DEPDIKBUD; 1990; 143) Pada prinsipnya pengertian keluarga dalam berbagai referensi hampir sama karena perbedaannya hanya terletak dalam pengungkapannya saja.

Pada dasarnya keluarga itu adalah sebuah komunitas dalam "satu atap". Kesadaran untuk hidup bersama dalam satu atap sebagai suami istri dan salling interaksi dan berpotensi punya anak akhirnya membentuk komunitas baru yang disebut keluarga. (Djamarah, 2004: 1617).

Keluarga merupakan satuan kekerabatan yang sangat mendasar dalam masyarakat. Biasanya terdiri dari ibu, bapak dengan anak-anaknya atau seisi rumah yang menjadi tanggungannya. Keluarga batih biasa disebut keluarga inti, yakni keluarga yang terdiri atas suami, 
isteri (suami atau isteri) dan anak. (Mantep Miharso; 2004; 13) Keluarga dalam sosiologi disebut batih, yaitu tempat lahir, tempat pendidikan, tempat perkembangan budi pekerti sianak. Batih juga lambang, tempat dan tujuan hidup bersama isteri. Batih yang kokoh dan sentosa menjadi sendi masyarakat yang sehat dan kuat. (Mantep Miharso; 2004; 30).

Islam memandang keluarga sebagai lingkungan atau milieu pertama bagi individu dimana ia berinteraksi. Dari interaksi dengan millieu pertama itu individu memperoleh unsurunsur dan ciri-ciri dasar dari pada kepribadiannya. Individu memperoleh akhlak, nilai-nilai, kebiasaan-kebiasaan dan emosinya dan dengan itu ia merubah banyak kemungkinankemungkinan, kesanggupankesanggupan dan kesediannya menjadi kenyataan yang hidup dan tindak laku yang tampak. (Hasan Langgulung; 2004; 292).

Jadi keluarga dapat dikatakan unit terkecil dari masyarakat yang terdiri atas suami dan isteri (ibu dan bapak) dan anak-anaknya yang tinggal pada suatu tempat dan saling ketergantungan. Keluarga dapat dibagi atas dua kategori:

a. Keluarga besar, yakni keluarga yang terdiri atas ibu, bapak dan beberapa anak serta lainlainnya.

b. Keluarga inti, yakni keluarga yang terdiri atas suami isteri.

Pembentukan keluarga dalam Islam berawal dengan terciptanya hubungan suci yang menjalin seorang laki-laki dengan seorang perempuan melalui perkawinan yang halal, dan memenuhi rukun-rukun dan syarat-syarat sahnya, oleh karena itu kedua suami isteri tersebut merupakan dua unsur utama dalam keluarga, dengan kata lain keluarga adalah perkumpulan yang halal antara seorang laki-laki dan perempuan yang bersifat terus-menerus dimana yang satu merasa tenteram dengan yang lain sesuai dengan ketentuan agama dan masyarakat. Dan ketika suami isteri tersebut dikaruniai seorang 
anak atau lebih, maka anak-anak itu menjadi unsur utama ketiga pada keluarga tersebut disamping dua unsur sebelumnya.

Ketiga unsur tersebut yakni, suami, isteri dan anak-anak masing-masing mempunyai peranan penting dalam membina dan menegakkan keluarga, sehingga kalau salah satu unsur hilang maka keluarga menjadi terganggu dan keluarga kehilangan keseimbangan.

Pentingnya unsur anak-anak ini banyak ayat-ayat Al Qur'an dan Hadits yang menegaskan bagaimana tabiat manusia suka mempunyai anak sebagai salah satu perhiasan hidup dan sumber kebahagiaan umat manusia jika anak-anak tersebut shaleh, sebagaimana firman Allah Swt.

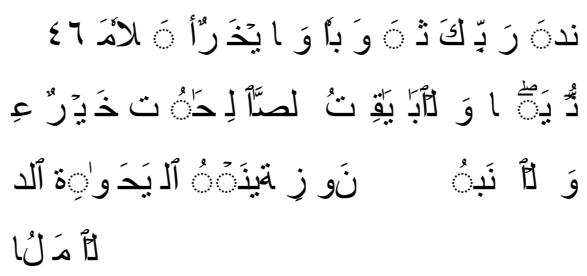

"Harta dan anak-anak adalah perhiasan kehidupan dunia tetapi amalan-amalan yang kekal lagi saleh adalah lebih baik pahalanya di sisi Tuhanmu serta lebih baik untuk menjadi harapan". AlKahf; 46) .
Setiap orang tua berkeinginan mempunyai anak yang berkepribadian baik, atau setiap orang tua bercita -cita mempunyai anak yang saleh yang senantiasa membawa harum nama orang tuanya, karena anak yang baik merupakan kebanggaan orang tua, baik buruknya kelakuan akan mempengaruhi nama baik orang tuanya. Untuk mencapai hal yang diinginkan itu dapat diusahakan melalui pendidikan. (Abdul Majid dan Dian Andayani; $137-138)$.

Keluarga merupakan ladang terbaik dalam penyemaian nilai -nilai tasawuf. Orang tua memiliki peranan yang strategis dalam mentradisikan tasawuf sehingga nilai - nilai tersebut dapat ditanamkan ke dalam jiwa anak. Kebiasaan orang tua dalam berperilaku baik misalnya sabar, tawakkal dan lain-lain akan menjadi suri tauladan bagi anak untuk mengikutinya. Di sinilah nilai -nilai tasawuf dapat bersemi dengan suburnya di dalam jiwa anak.

Kepribadian yang luhur agamis yang membalut jiwa anak menjadikannya insane -insan yang 
penuh iman dan takwa kepada Allah SWT.

\section{Penanaman Nilai-Nilai Tasawuf Dalam Keluarga}

Secara etimologi, para ahli berselisih tentang asal kata tasawuf, antara lain: ahlu Suffah, yang berarti sekelompok orang pada masa Rasulullah Saw. Yang hidupnya berdiam diserambi-serambi masjid, mereka mengabdikan hidupnya untuk beribadah kepada Allah Swt. (Rosihan Anwar; 2010; 143) Ada juga yang berpendapat bahwa tasawuf berasal dari Shaf (barisan), karena kaum sufi mempunyai iman kuat, jiwa bersih, ikhlas, senantiasa memilih barisan yang paling depan dalam shalat berjamaah atau dalam perang suci.( M.Solihin, Rosihan Anwar; 2008; 11) Akar kata lain dari tasawuf adalah Safa: bersih atau jernih, Saufanah: Sebutan nama kayu yang bertahan tumbuh di padang pasir, serta Suf (bulu domba), disebabkan karena kaum sufi biasa menggunakan pakaian dari bulu domba yang kasar. Saat itu, para sufi memakai bulu untuk pakaiannya sebagai simbol untuk merendahkan diri dan kesederhanaan pada masa itu. (A. Rivay Siregar; 2002; 31) Orang yang berpakaian bulu domba disebut mutasawwif, sedangkan perilakunya disebut tasawuf. Sehingga sebutan sufi diberikan kepada siapa pun yang mampu menjaga keseimbangan dalam berkehidupan, dengan artian yang tidak jauh dari pengertian sufi sebagai pelaku ajaran tasawuf.

$$
\text { Sedangkan menurut }
$$

terminologi tasawuf diartikan secara variatif oleh para ahli sufi, antara lain, yaitu: menurut tokoh sufi Junayd alBaghdadi, tasawuf adalah membersihkan hati dari apa yang mengganggu perasaan kebanyakan makhluk, berjuang meninggikan budi pekerti, memadamkan sifat-sifat kelemahan manusia, menjauhi segala seruan dari hawa nafsu, menghendaki sifat-sifat suci keruhanian, dan bergantung pada ilmu-ilmu hakikat, memakai barang yang terlebih penting dan terlebih kekal, menaburkan nasihat kepada sesama umat, memegang teguh janji dengan Allah dalam segala hakikat, dan mengikuti contoh Rasulullah dalam segala syari'at.( M. Zain Abdullah; 2007; 11-12) Sementara, tasawuf 
menurut alGhazali adalah akhlak. Barangsiapa yang memberikan bekal akhlak atasmu, berarti ia memberikan bekal atas dirimu dalam tasawuf, maka jiwa seorang hamba adalah menerima (perintah) untuk beramal karena mereka sesungguhnya melakukan suluk kepada sebagian akhlak karena keadaan mereka yang bersuluk dengan Nur (cahaya) iman.( A Mustofa; 1999; 203-204).

Menurut Hamka, tasawuf adalah akhlak yang luhur (ihsan) yang merupakan refleksi penghayatan keagamaan esoterik yang mendalam, tetapi tidak dengan serta merta melakukan pengasingan diri ('uzlah). Pemahaman lebih jauh tentang tasawuf yang tepat sebagaimana yang didefinisikan Hamka, bahwa tasawuf akan menjadi positif, bahkan sangat positif kalau tasawuf dilaksanakan dalam bentuk kegiatan keagamaan yang searah dengan muatan-muatan peribadahan yang telah dirumuskan sendiri oleh al-Qur'an dan al-Sunnah serta dilaksanakan dalam bentuk kegiatan yang berpangkal pada kepekaan sosial yang tinggi dalam arti kegiatan yang dapat mendukung "pemberdayaan umat Islam" agar kemiskinan ekonomi, pendidikan, ilmu pengetahuan, kebudayaan, politik dan mentalitas, serta esklusivitas dalam dunia tasawuf sebagai satu bagian stigma yang harus dipugar menjadi tasawuf yang lebih ramah pada realitas, sehingga kemudian terciptalah satu tasawuf yang inklusif. (Hamka: Nurcholis Madjid; 1995: 94).

Tasawuf merupakan bagian dari keilmuan Islam yang bersumber pada al-Qur'an dan Sunnah yang dimaknai dan dihayati secara esoteris sehingga sangat kaya dengan nilainilai spiritual, yang tentu saja dapat dikontekstualisasikan maknanya dalam berbagai kehidupan manusia secara lebih luas. Dengan demikian tasawuf merupakan sebuah upaya untuk membersihkan pandangan, memurnikan orientasi, meluruskan niat dan cara bersikap untuk tidak terlalu mementingkan "yang selain Allah" (dunia). Karena didalam tasawuf terdapat nilai-nilai yang menjadi hal penting untuk tasawuf itu sendiri. Pada kenyataanya dimasa sekarang ini nilai-nilai tasawuf itu sendiri mulai diabaikan. Padahal jika nilai-nilai tersebut bisa ditanamkan 
dalam kehidupan sehari-hari didalam keluarga, maka peluang untuk mendapatkan masyarakat islami itu sangat besar, dengan kesopansantunan dan kekentalan unsur spritual. Sehinnga dengan tasawuf dapat mengarah pada keseimbangan hidup manusia dalam berbagai aspeknya, yaitu jasmani rohani, atau dunia akherat, kebutuhan individu atau masyarakat.

Pengejawantahannya,manusia berusaha untuk mendekatkan diri kepada Allah dengan sedekat mungkin melalui metode penyucian rohani maupun dengan memperbanyak amalan ibadah dan dzikir, sehingga dengan itu segala konsentrasi seseorang hanya tertuju kepadaNya.

Beberapa nilai-nilai tasawuf yang bisa diterapkan dalam kehidupan sehari-hari adalah sebagai berikut:

1. Taubat

Taubat berasal dari bahasa Arab taba, yatubu, taubatan, yang artinya kembali (Mahmud Yunus; 1990; 79). Menurut kalangan sufi taubat adalah memohon ampun atas segala dosa dan kesalahan disertai janji yang sungguh-sungguh tidak akan mengulangi perbuatan dosa tersebut, yang disertai dengan melakukan amal kebajikan. (Abuddin Nata;2002; 198).

Taubat merupakan kewajiban bagi setiap muslim, karena selama ia belum mampu melaksanakan ibadah kepada Allah secara sempurna, maka itu berarti ia tidak kebal dari godaan-godaan setan yang senantiasa mengajak jiwa rendahnya kepada perbuatanperbuatan yang menyimpang dan terlarang. Bahkan, dalam pandangan AlGhazali, bertaubat dengan segera merupakan kewajiban yang tak diragukan lagi, karena adanya sebuah pengetahuan bahwa maksiat-maksiat yang dilakukan akan menghancurkan sendi-sendi iman.

Kata taubat sering dikaitkan dengan kata dosa dan maksiat. Karena taubat selalu dilakukan karena orang tersebut sebelumnya telah meninggalkan Allah dan melanggar perintah-Nya dengan berbuat maksiat dan dosa. Karenanya sadar dan menyesal atas perbuatan dosa dan maksiatnya dan 
kembali kepada Allah dalam arti taat dan patuh, maka orang tersebut telah bertaubat.

Dalam ajaran Islam taubat memiliki pengertian yang sangat luas karena taubat berhubungan dengan penataan kembali kehidupan manusia yang sudah berantakan dan perbaikan kembali mental seseorang yang sudah rusak akibat dosa yang diperbuat.

Bila dikaji dari aspek psikologis, taubat merupakan suatu kombinasi dari fungsi-fungsi kejiwaan yang terdiri atas kesalahan, yaitu pengetahuan mengenai pengaruh negatif dari perbuatan dosa, diiringi dengan penyesalan sepenuh hati untuk memohon ampun kepada Allah, disertai motivasi yang kuat unuk meninggalkan perbuatan dosa dengan segera, dan menebus dosa dengan mengisi kehidupannya dengan amalan saleh, serta keinginan untuk memperbaiki diri dan menata kembali kehidupan yang lebih baik di masa mendatang. Apabila unsur•unsur taubat di atas dapat terjalin dalam satu kesatuan kepribadian orang yang bertaubat, maka dapat dibayangkan betapa besar manfaat taubat bagi manusia. Selanjutnya "ketika seorang hamba beraubat, memohon ampunan dan mensucikan jiwa, maka cinta Ilahiyah itu melimpahi seluruh jiwa hambanya, dan kelak sosok seorang hamba mengalami reproduksi spiritual yang luar biasa.

Selain itu menurut Afif Abdul Fattah Thabbarah manfaat taubat di bagi menjadi beberapa bagian, di antaranya :

a. Memberi harapan baru bagi jiwa yang telah mengalami kehancuran akibat perbuatan dosa untuk dapat dibersihkannya kembali. Harapan ini akan membuat jiwanya tenang dan memandang kehidupan dengan gairah baru yang dipenuhi dengan keoptimisan, serta tidak pernah gentar mengahdapi tantangan.

b. Dengan melakukan taubat, seseorang akan menghargai dirinya. Perasaan hormat ini akan tumbuh dari dirinya sendiri. Atau dengan kata lain, taubat akan membuat seseorang akan lebih mempercayai dirinya sendiri. Kenyataan seperti ini merupakan modal pertama bagi 
pembentukan suatu kepribadian yang lebih utama.

c. Taubat akan menjadikan jiwa pelaku dosa akan menjadi stabil dan tentram. Sebelum itu, jiwanya penuh dengan pertarungan sengit akibat perbuatan dosa yang pernah dilakukannya. Seseorang yang telah stabil jiwanya akan sulit tergoyahkan di dalam menghadapi segala bentuk tantangan. Bahkan semuanya itu akan dihadapi dengan penuh keberanian secara realistis.

d. Taubat juga dapat membebaskan seseorang dari tekanan perasaan berdosa dan merasa takut. Sebab, seseorang yeng telah melakukan dosa, maka akan merasakan dirinya celaka dan terganggu oleh tegangan-tegangan dari dalam jiwanya sendiri. Hal ini terjadi lantaran merasa takut yang luar biasa terhadap malapetaka yang akan menimpanya akibat perbuatan dosa.( Afifi Abdul Fatlah Thabbarah; 1993; 46)

2. Zuhud

Secara etimologis zuhud berarti ragaba 'ansyai'in wa tarakahu, artinya tidak tertarik terhadap sesuatu dan meninggalkannya. Zahada fi aldunya, berarti mengosongkan diri dari kesenangan dunia untuk ibadah. Orang yang melakukan zuhud disebut zahid, zuhhad atau zahidun. (Amin Syukur; 1997;1) .

Menurut terminologi, zuhud adalah mengarahkan keinginan kepada Allah SWT. Menyatukan kemauan kepadaNya, dan sibuk denganNya dibanding kesibukan lainnya agar Allah SWT membimbing dan memberikan petunjuk seorang zahid.

Kandungan zuhud membangkitkan semangat spiritual yang tinggi. Seorang zahid menahan jiwanya dari pelbagai bentuk kenikmatan dan kelezatan hidup duniawi, menahan dorongan nafsu yang berlebihan agar memperoleh kebahagiaan yang abadi. Seorang zahid juga mengikis habis nilai yang akan menghalanginya untuk memperoleh rahmat dan kelezatan hidup di bawah naungan Allah. Kecintaan kepada Allah mengalahkan segala alternatif yang mendorong kepada hubb Asy-shahawat (cinta untuk menuruti hawa nafsu). Perasaan 
naluri memberi kesaksian ke atas kecintaan, kedamaian, dan kebahagiaan hubungan dengan Rabb ketika ia lebih mengutamakan kebenaran berbanding dorongan hawa nafsu. (A.Bachrun Rifae I dan Hasan Mud is; 2010; 208).

Dengan demikian zuhud merupakan jalan seseorang untuk meninggalkan segala sesuatu yang sekiranya akan membuat dirinya lupa akan keberadaan Allah. Mereka tidak hanya meninggalkan sesuatu yang syubhat saja, namaun mereka juga membatasi dari hal-hal yang di halalkan apabila hal tersebut dapat menjauhkan dirinya dari zikir kepada Allah. Didalam diri seorang zahid tidak ada kecintaan dunia melebihi kecintaannya kepada Allah. Mereka menolak terhadap kecintaan dunia, tapi mereka tidak menafikkan segala rizki yang datang kepadanya, mereka menggunakan rizki itu untuk lebih mendekatkan diri kepada Allah Swt..

3. Wara

Secara harfiah wara artinya menahan diri, berhati-hati, atau menjaga diri supaya tidak jatuh pada kecelakaan (Rakhmat; 2001; 101).

Dalam tradisi sufi, yang disebut Wara adalah meninggalkan segala sesuatu yang tidak jelas atau belum jelas hukumnya (syubhat). Hal ini berlaku pada segala hal atau aktifitas kehidupan manusia, baik yang berupa benda maupun perilaku. Seperti makanan, minuman, pakaian, pembicaraan, perjalanan, duduk, berdiri, bersantai, bekerja dan lain-lain. (Hasyim Muhammad ; 2002; 31).

Wara' harus dimaknai secara arif dan bijaksana, yaitu menjaga kesucian lahir dan batin serta kemampuan menghindari persoalan yang haram atau syubhat. Sikap wara' memiliki jangkauan yang cukup luas, yaitu meliputi pandangan, pendengaran, lisan, perut, kemaluan, jual beli dan lainlain.

Banyak orang yang terjebak ke dalam perkara-perkara yang diharamkan dan syubhat karena meremehkan hal tersebut, yaitu bersikap wara' dalam menjaga lisan, perut dan pandangan. Untuk menjaga lisan, perut dan pandangan 
ini harus berbekal ilmu pengetahuan yang mapan yang disertai landasan iman dan takwa.

Imam Al-Ghazali (Ahmad, 1993: 56-58) membagi wara' menjadi empat golongan berikut:

1. Wara'-nya orang awam, yaitu wara'-nya orang biasa yang mampu menahan diri dari melakukan sesuatu yang dilarang oleh agama.

2. Wara'-nya orang shalih, yaitu wara'-nya orang yang mampu menahan diri dari menyentuh atau memakan sesuatu yang mungkin akan jatuh kepada yang haram, yaitu makan sesuatu yang tidak jelas hukum atas statusnya (syubhat).

3. Wara'-nya orang bertakwa, yaitu wara'-nya orang yang mampu menahan diri dari sesuatu yang tidak diharamkan oleh agama, dan bukan pula termasuk sesuatu yang syubhat, tetapi ia menahan diri dari perkara tersebut karena takut kepada yang haram, yakni meninggalkan sesuatu yang tidak ada apa-apa karena takut kepada apa-apa. Pada tingkatan ini, orang tersebut selalu menjaga dan mengendalikan diri dari keinginan melakukan sesuatu perbuatan, mengucapkan sesuatu perkataan atapun memakan sesuatu makanan karena khawatir akan jatuh ke dalam dosa.

4. Wara'-nya orang benar, yaitu wara'-nya orang yang mampu menahan diri dari dosa karena Allah SWT. Artinya, setiap gerak-gerik orang ini hanya diperuntukkan beribadah kepada Allah SWT sehingga segala sesuatu yang tidak diniatkan beribadah, maka hukum bagi dirinya sendiri adalah haram.

Lebih jauh dikatakan Ibnu Qayyim Al-Jawziyah membagi wara' dalam tiga tahap, yaitu tahap meninggalkan kejelekan, tahap menjauhi hal yang diperbolehkan karena kuatir jatuh pada hal-hal yang dilarang, dan tahap menjauhi apa saja yang membawa orang kepada selain Dia (Rakhmat, 2001: 104).

Seseorang yang memiliki sifat wara' senantiasa akan menjaga kesucian baik perilaku maupun rohaninya dengan mengendalikan segala perilaku aktifitas kesehariannya, dan ia hanya akan melakukan sesuatu jika sesuatu 
tersebut bermanfaat baik untuk dirinya sendiri maupun untuk orang lain. Disamping itu ia juga tidak akan menggunakan sesuatu hal yang belum jelas statusnya. Dengan demikian maka raga dan jiwanya senantiasa terjaga dari halhak yang tidak diridhai Allah Swt. Karena itu seorang sufi tidak melihat suatu benda atau perilaku seseorang dari wujud kasarnya atau keelokan rupanya, tetapi seorang sufi melihat sesuatu baik benda, perilaku, maupun gagasan atau pemikiran dari nilai yang terkandung didalamnya tanpa melihat bentuk fisik karena para sufi menjadikan nilai sebagai hal yang substansial.

Sementara kekayaan, gelar, jabatan maupun status sosial lainnya bagi seorang sufi bukanlah hal yang menentukan kualitas seseorang dimata Allah Swt. Yang menentukan derajat seseorang tidak melihat suatu benda atau perilaku seseorang dari wujud kasarnya atau keelokan rupanya, tetapi seorang sufi melihat sesuatu baik benda, perilaku maupun gagasan pemikiran dari nilai yang terkandung didalamnya tanpa melihat bentuk fisik. Para sufi menjadikan nilai sebagai sesuatu yang su bstansial, sementara kekayaan, gelar, jabatan atau status social lainnya bagi seorang sufi bukanlah hal yang menentukan kualitas seseorang dimata Allah Swt. Karena yang menentukan derajat seseorang adalah sejauh mana segala hal tersebut mengandung nilai-nilai yang dapat mensucikan diri dari kotoran yang telah menjauhkannya dari kodrat asal penciptaannya yang paling sempurna dibanding dengan makhluk lain. (Mutamam: 2009; 33)

\section{Faqir}

Secara etimologi Faqir berarti membutuhkan atau memerlukan atau orang miskin. Kata faqir mengandung pengertian miskin terhadap spiritual atau hasrat yang sangat besar terhadap pengosongan jiwa untuk menuju kepada Allah SWT. ( Samsul Munir Amin; 2012; 172).

Faqir diartikan sebagai kekurangan harta yang diperlakukan seseorang dalam menjalani kehidupan dunia. Sikap 
fakir menjadi penting dimiliki orang yang sedang berjalan menuju Allah, karena harta memungkinkan manusia dekat pada kejahatan dan membuta jiwa tertambat pada selain Allah. Fakir yang sesungguhnya adalah tidak memiliki sesuatu dan hatinya juga tidak menginginkan sesuatu. Faqir adalah tidak menuntut lebih banyak dari apa yang telah dipunyainya, dia merasa puas dengan apa yang dimiliki.

Sikap mental Faqir merupakan benteng yang kuat untuk menahan pengaruh kehidupan materi, sikap faqir sebagai tameng dari keserakahan, kerakusan, tamak, dan sebagainya, karena fakir adalah maqam yang bertujuan membersihkan jiwa,dan menganggap tidak ada yang lebih penting selain dekat dengan Allah

5. Sabar

Kata sabar berasal dari kata mempunyai arti, bersabar, tabah hati, berani. (Mahmud Yunus; 211). Dalam kamus besar Bahasa Indonesia, sabar diartikan sebagai tahan menghadapi cobaan (tidak lekas marah, tidak lekas putus asa, tidak lekas patah hati), dalam hal ini sabar sama halnya dengan tabah". (Depdikbud; 1990; 763) secara terminologi para ahli mengartikan sabar dengan berbagai macam pengertian, sebagaimana yang diungkapkan oleh alMaraghi, sabar adalah ketabahan hati dalam menanggung berbagai macam kesulitan sebagai upaya mencegah perbuatan-perbuatan yang tidak disukai dan dalam rangka melaksanakan ibadah, serta ketabahan dalam menjauhi perbuatan-perbuatan maksiat. (Ahmad Musthafa Al-Maraghi; $1992 ; 10)$.

Sabar menurut Dzunnun alMishry adalah menjauhkan diri dari segala sesuatu yang bertentangan dengan syariat, tenang saat ditimpa musibah, dan menampakkan kecukupan ketika dalam kefakiran. (Amin Syukur; 2012; 60).

Menurut Ibnu Qayyim alJauziyyah, sabar artinya menahan diri dari rasa gelisah, cemas dan amarah; menahan lidah dari keluh kesah; menahan anggota tubuh dari kekacauan. Menurut Achmad Mubarok, pengertian sabar adalah 
tabah hati tanpa mengeluh dalam menghadapi godaan dan rintangan dalam jangka waktu tertentu dalam rangka mencapai tujuan. Menurut Muhammad Rabbi Muhammad Jauhari bahwa para ulama menyebutkan sejumlah definisi bagi sabar, di antaranya:

a. Meneguk cairan pahit tanpa muka mengerut.

b. Diam terhadap musibah,

c. Berteguh hati atas aturan-aturan Al-Quran dan As-Sunnah,

d. Tak pernah mengadu,

e. Tidak ada perbedaan antara sedang nikmat dan sedang diuji meskipun dua-duanya mengandung bahaya (Muhammad Rabbi Muhammad Jauhari; 2006; 342)

Dengan demikian sabar dapat dijadikan sebagai sarana penyembuhan yang ampuh. ketika mendapat ujian berupa sakit, maka seseorang dapat menggunakan kesabarannya dalam menahan serangan rasa sakit dengan mengembalikannya kepada Allah. Sabar atas segala keputusan-Nya, sehingga rasa sakit justru menjadi sarana untuk mendekatkan diri kepada Allah dan memahami betapa besar kekuasaannya.

Sabar juga bermakna kemampuan mengendalikan emosi, maka nama sabar berbedabeda tergantung obyeknya.

1. Ketabahan menghadapi musibah, disebut sabar, kebalikannya adalah gelisah (jaza') dan keluh kesah (hala').

2. Kesabaran menghadapi godaan hidup nikmat disebut, mampu menahan diri (dlobith an nafs), kebalikannya adalah tidak tahanan (bathar).

3. Kesabaran dalam peperangan disebut pemberani, kebalikannya disebut pengecut

4. Kesabaran dalam menahan marah disebut santun (hilm), kebalikannya disebut pemarah (tazammur).

5. Kesabaran dalam menghadapi bencana yang mencekam disebut lapang dada, kebalikannya disebut sempit dadanya.

6. Kesabaran dalam mendengar gossip disebut mampu menyembunyikan rahasia (katum), 
7. Kesabaran terhadap

6. Tawakkal

kemewahan disebut zuhud,

Dalam Kamus Umum

kebalikannya disebut serakah, loba (al hirsh).

8. Kesabaran dalam menerima yang sedikit disebut kaya hati (qana'ah), kebalikannya disebut tamak,

rakus

\{ syarahun).(Hasyim

Muhammad; 2002;. 44).

Dengan demikian pada dasarnya kesabaran adalah wujud dari konsistensi diri seseorang untuk memegang prinsip yang telah dipegangi sebelumnya. Atas dasar itu maka al-Quran mengajak kaum muslimin agar berhias diri dengan kesabaran. Sebab, kesabaran mempunyai manfaat yang sangat besar dalam membina jiwa, memantapkan kepribadian, meningkatkan kekuatan manusia dalam menahan penderitaan, memperbaharui kekuatan manusia dalam menghadapi berbagai problem hidup, beban hidup, musibah, dan bencana, serta menggerakkan kesanggupannya untuk terus-menerus berjihad dalam rangka meninggikan kalimah Allah .SWT.

Bahasa Indonesia, tawakal berarti berserah (kepada kehendak Tuhan), dengan segenap hati percaya kepada Tuhan terhadap penderitaan, percobaan dan lainlain. (W.J.S. Poerwadarminta; 1976; 1026) Sedangkan dalam Kamus Modern Bahasa Indonesia, tawakal berarti jika segala usaha sudah dilakukan maka harus orang menyerahkan diri kepada Allah yang Maha kuasa. (Sutan Muhammad Zain; tth; 956).

Menurut Imam Al-Ghazali, tawakal adalah pengendalan hati kepada Tuhan Yang Maha Pelindung karena segala sesuatu tidak keluar dari ilmu dan kekuasaan-Nya, sedangkan selain Allah tidak dapat membahayakan dan tidak dapat memberinya manfaat. (Imam Al-Ghazali, Muhtasar Ihya Ulumuddin, Terj. Zaid Husein al-Hamid; 1995; 290). Menurut TM. Hasbi AshShiddieqy, tawakal adalah menyerahkan diri kepada Allah dan berpegang teguh kepada-Nya.(TM. Hasbi Ash Shiddieqy; 2001;534). Lebih jauh menurut beliau bahwa, 
tawakal bukanlah sikap meninggalkan usaha, menanti apa saja yang akan terjadi dengan berpeluk lutut dan berpangku tangan, menerima saja sesuatu qada dengan tidak mencari jalan mengelakkan diri dari padanya. Menurut Hasbi, adalah keliru bila orang yang menganggap tawakal dengan memasrahkan segalanya kepada Allah SWT tanpa diiringi dengan usaha maksimal. Usaha dan ikhtiar itu harus tetap dilakukan, sedangkan keputusan terakhir diserahkan kepada Allah Swt. Tawakal tanpa ikhtiar adalah suatu dosa. Sebaliknya ikhtiar tanpa tawakal juga berdosa karena itu menunjukkan hamba yang angkuh.

Hamka menyatakan bahwa tawakal adalah menyerahkan keputusan segala perkara, ikhtiar dan usaha kepada Allah Swt. Serta berserah diri sepenuhnya kepadaNya untuk mendapatkan kemaslahatan atau menolak kemudaratan. (Hamka;1990; 232 233).

Menurut Imam Al-Ghazali, tawakal adalah pengendalan hati kepada Tuhan Yang Maha
Pelindung karena segala sesuatu tidak keluar dari ilmu dan kekuasaan-Nya, sedangkan selain Allah tidak dapat membahayakan dan tidak dapat memberinya manfaat. (Imam AlGhazali,Terj. Zaid Husein al-Hamid: 1995: 290).

Menurut ajaran Islam, tawakal itu adalah landasan atau tumpuan terakhir dalam sesuatu usaha atau perjuangan. Baru berserah diri kepada Allah setelah menjalankan ikhtiar.

Itulah sebabnya meskipun tawakal diartikan sebagai penyerahan diri dan ikhtiar sepenuhnya kepada Allah SWT, namun tidak berarti orang yang bertawakal harus meninggalkan semua usaha dan ikhtiar. Sangat keliru bila orang menganggap tawakal dengan memasrahkan segalanya kepada Allah SWT tanpa diiringi dengan usaha maksimal. Usaha dan ikhtiar itu harus tetap dilakukan, sedangkan keputusan terakhir diserahkan kepada Allah Swt. Di dalam alQur'an, Allah Swt menegaskan:

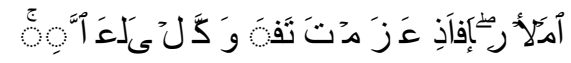

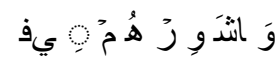


"Dan bermusyawarahlah dengan mereka pada setiap urusan, apabila engkau telah berketetapan hati, maka menyerah dirilah engkau kepada Allah. (Q,S. Ali-Imran/3:159). (Depag RI; 2004; 109).

Orang yang bertawakal kepada Allah SWT tidak akan berkeluh kesah dan gelisah, tetapi akan selalu berada dalam ketenangan, ketenteraman, dan kegembiraan. Jika memperoleh nikmat dan karunia dari Allah SWT, selalu bersyukur, dan jika tidak atau mendapat musibah, akan bersabar dan menyerahkan semua keputusan, bahkan dirinya sendiri kepada Allah SWT. Penyerahan diri itu dilakukan dengan sungguhsungguh dan semata-mata karena Allah Swt.sehingga tawakal akan membuat seseorang penuh percaya diri, memiliki keberanian dalam menghadapi setiap persoalan, memiliki ketenangan dan ketenteraman jiwa, dekat dengan Allah SWT dan menjadi kekasihNya, dipelihara, ditolong, dan dilindungi Allah SWT, diberikan rezeki yang cukup, dan selalu berbakti serta taat kepada Allah SWT, disamping itu orang yang tawakal akan mampu menerima dengan sabar segala macam cobaan dan musibah. Berbagai musibah dan malapetaka yang melanda Indonesia telah dirasakan masyarakat. Bagi orang yang tawakal maka ia rela menerima kenyataan pahit, sementara yang menolak dan atau tidak tawakal, ia gelisah dan protes dengan nasibnya yang kurang baik.

Dengan demikian sikap tawakkal bukan sekedar berserah diri kepada Allah (pasrah terhadap taqdir) , mengenai apa -apa yang akan terjadi dalam kehidupan, tetapi sikap tawakkal akan muncul ketika seseorang telah berusaha semaksimal mungkin untuk mencapai tujuan yang diinginkan. Dengan sikap tawakkal seseorang akan mampu meredam rasa kekecewaan jika apa yang diinginkan itu tidak terpenuhi, karena dengan itu seseorang akan menyadarinya bahwa usaha yang dilakukan masih ada campur tangan dari Allah. Oleh karena itu ketika tujuan yang diinginkan tidak terpenuhi seseorang akan mengetahuinya mungkin Allah mempunyai rencana yang lebih baik dari kegagalan usaha yang dilakukan. 
7. Ridha

Ridha berati menerima dengan rasa puas terhadap apa yang dianugerahkan Allah Allah Swt. Ridha digambarkan sebagai keteguhan di hadapan qadha. Orang yang ridha mampu melihat hikmah dan kebaikan dibalik cobaan yang diberika Allah dan tidak berburuk sangkat terhadap ketentuan Allah, sehingga tidak mengeluh dan tidak merasakan sakit atas cobaan Nya. Melainkan merasakan cobaan sebagai nikmat, lantaran jiwanya bertemu dengan yang dicintainya.

Ridha juga dapat diartikan dengan perasaan gembira atau senang hati dalam menerima keputusan Allah swt. Ridha mencerminkan ketenangan jiwa seseorang. Orang yang mempunyai sikap ridha, akan dapat merasakan nikmat yang telah diberikan oleh Allah swt dan juga mensyukuri segala nikmat yang Allah swt berikan. Orang yang berperilaku Ridha juga akan tabah dan sabar dalam menerima cobaan atau musibah yang menimpanya.

Orang yang mampu mencapai ridha kepada Allah akan memiliki sikap optimis,lapang dada, kosong hatinya dari dengki, selalu berprasangka baik, bahkan lebih dari itu, yaitu memandang baik, sempurna, penuh hikmah, semua yang terjadi semua sudah ada dalam rancangan dan ketentuan Allah.

Berbeda dengan orangorang yang selalu membuat kerusakan di muka bumi ini, mereka selalu ridha apabila melakukan perbuatan yang Allah haramkan, dalam hatinya selalu merasa kurang apabila meninggalkan kebiasaan buruk yang selama ini mereka perbuat, dengan kata lain merasa puas hati apabila aktivitas hidupnya bisa membuat risau, khawatir, dan selalu mengganggu terhadap sesamanya. Semuanya itu ia lakukan karena mengikuti hawa nafsu yang tanpa ia sadari bahwa sebenarnya syaitan telah menjerat dirinya dalam perbuatan dosa.

Penerapan nilai-nilai tasawuf tersebut di atas didalam keluarga merupakan sebuah proses pelaksanaan suatu idealisme yang menyangkut persoalan keyakinan terhadap yang dikehendaki serta 
memberikan corak pada pola pikiran, perasaan dan perilaku seseorang dalam mencari jalan menuju Allah dengan membebaskan diri dari pengaruh kehidupan duniawi. Sehingga nilai nilai tasawuf itu dapat menjadi suatu kepribadian yang selalu melekat dalam jiwa agar tidak terjerumus dalam kenistaan.

Agar penanaman nilai-nilai tasawuf diatas dapat berhasil dengan baik dalam keluarga, sangat penting bagi orang tua untuk menciptakan kondisi atau suatu proses yang mengarahkan anak untuk melaksanakan dalam kehidupannya, ada beberapa metode yang bisa dilakukan adalah:

1. Metode Keteladanan

Keteladanan merupakan metode yang paling baik dalam rangka bimbingan orang tua kepada anaknya. Setiap anak yang akan menjalani proses kehidupannya, mereka memerlukan keteladanan yang baik dan saleh dari orang tuanya. Manusia itu memiliki kebutuhan psikologis untuk menyerupai dan mencontoh orang yang dicintai dan dihargainya. (Ali Badawi; 2002; 13). Karena kedudukan orang tua merupakan sentral figur bagi anak-anaknya. Apabila orang tua memberi contoh yang kurang baik dalam perilakunya, maka seorang anak akan sulit berbuat yang baik.

$$
\text { Dengan demikian }
$$

keteladanan yang diberikan orang tua pada anak-anaknya akan sangat menentukan keberhasilan orang tua dalam membimbing anak-anaknya. Dan metode inilah yang paling efektif untuk membimbing anaknya. Orang tua tidak hanya memberikan bimbingan secara lisan melainkan juga langsung memberikan contoh kepada anak-anaknya.

2. Metode Pembiasaan

Pembiasaan merupakan salah satu metode dalam mendidik dan membimbing anak, yaitu dengan cara membiasakan anak untuk melakukan perbuatan yang diajarkan dalam agama. Pembentukan kebiasaan pada anak mulai sejak dini sangat 
penting,

utamanya

pembentukan

kebiasaan-

kebiasaan yang bersifat

relegius, sesuai dengan

perkembangan jiwanya, oleh

karena itu seharusnya orang tua

bisa menanamkan kebiasaan-

kebiasaan berprilaku baik mulai

sejak dini. Karena masa anakanak adalah masa yang paling baik untuk menanamkan dasardasar kehidupan beragama. Misalnya anak-anak dibiasakan ikut serta kemasjid bersamasama untuk menjalankan ibadah, mendengarkan ceramah keagamaan, kegiatan seperti inilah yang sangat besar sekali pengaruhnya terhadap kepribadian anak selanjutnya.

3. Metode Hukuman

Hukuman merupakan sebuah metode terburuk, tetapi dalam kondisi tertentu harus digunakan. Hukuman adalah sebuah metode/cara yang paling akhir. Oleh sebab itu ada beberapa hal yang perlu diperhatikan dalam menggunakan hukuman. (Hery Noer Aly; 1999; 178). :
1. Hukuman adalah metode kuratif, artinya tujuan hukuman ialah untuk memperbaiki kesalahan.

2. Hukuman baru digunakan apabila metode lain tidak berhasil guna dalam memperbaiki kesalahan .

3. Sebelum dijatuhi hukuman, hendaknya lebih dahulu di beri kesempatan untuk bertaubat dan memperbaiki diri.

4. Hukuman yang dijatuhkan dapat dimengerti, sehingga menyadari akan kesalahannya dan tidak mengulanginya.

5. Hukuman psikis lebih baik dari pada hukuman fisik.

6. Hukuman hendaknya disesuaikan dengan latar belakang kondisi anak.

7. Dalam menjatuhkan hukuman, hendaknya diperhatikan prinsip logis, yaitu hukuman disesuaikan dengan jenis kesalahan.

8. Hendaknya tidak melakukan ancaman hukuman yang tidak mungkin dilakukan.

Dari penjelasan diatas bahwa orang tua harus dapat menjadi teladan utama, dan membiasakan anak-anaknya untuk melakukan perbuatan yang baik. 
Dengan demikian ditanamkannya nilai nilai tasawuf dalam keluarga dalam rangka melatih manusia agar memiliki ketajaman batin dan kehalusan budi pekerti. Sikap batin dan kehalusan budi yang tajam ini menyebabkan ia akan selalu mengutamakan pertimbangan kemanusiaan pada setiap masalah yang dihadapi dengan demikian ia akan terhindar dari melakukan perbuatan perbuatan yang tercela menurut agama.

Ajaran tawakkal pada Tuhan menyebabkan ia memiliki pegangan yang kokoh, karena ia telah mewakilkan atau menggadaikan dirinya sepenuhnya pada Tuhan, sikap tawakkal ini akan mengatasi sikap stress yang dialami oleh manusia. Sikap materialistik dan hedonistik yang merajalela dalam kehidupan modern ini dapat diatasi dengan menerapkan konsep zuhud, yang pada intinya sikap yang tidak mau diperbudak atau terperangkap oleh pengaruh duniawi yang sementara itu.

Jika sikap ini tidak mantap, maka ia tidak akan berani menggunakan segala cara untuk mencapai tujuan, sebab tujuan yang ingin dicapai dalam tasawuf adalah menuju Tuhan, maka caranyapun harus ditempuh dengan cara yang disukai Allah Swt.

Karena menurut Ibn Taymiyyah, hati seperti halnya tubuh yang perlu dipelihara dengan diberi gizi yang cukup dan dijauhkan dari segala yang merusak. Hati manusia akan tumbuh dan berkembang menjadi semakin baik jika diberi sesuatu yang bermanfaat dan dijauhkan dari segala yang merusak. Langkah menjauhi maksiat dan meninggalkan perbuatan keji (fawahisy) dapat menjadikan hati bersih. Hal ini dapat dimengerti karena kedudukan maksiat seperti cairan kotor dalam tubuh. Apabila hati bertobat atas dosa-dosa yang diperbuat dengan membersihkan bercampurnya amal saleh dengan kemaksiatan yang ada di dalamnya, maka kekuatan hati akan kembali pulih. Keinginan untuk beramal saleh akan bangkit dan selanjutnya hati akan terbebas dari hal-hal buruk yang menggerogotinya.

Allah berfirman dalam alQur'an Surat asy-Syam ayat 9 - 
10,yang artinya: " Sesungguhnya beruntunglah orang yang mensucikan jiwa itu, dan Sesungguhnya merugilah orang yang mengotorinya. Penanaman nilai-nilai tasawuf dalam keluarga pada dasarnya bertujuan untuk memupuk sifat ihsan dalam perilaku sehari-hari sehingga merasakan kedekatan diri dengan sang Khaliq dan akan menimbulkan kesadaran untuk melaksanakan ajaran-ajaran agama Islam dengan istiqamah.

\section{Simpulan}

Keluarga merupakan unit pertama dan institusi pertama dalam masyarakat di mana hubunganhubungan yang terdapat di dalamnya, sebahagian besarnya bersifat hubungan langsung dan di situlah berkembang individu dan di situ pulalah terbentuknya tahap-tahap awal proses sosialisasi bagi anakanak. Dari interaksi dalam keluarga inilah anak-anak memperoleh pengetahuan, keterampilan, minat, nilai-nilai, emosi dan sikapnya dalam hidup dan dengan itu pulalah mereka memperoleh ketenteraman dan ketenangan.
Keluarga memiliki peran penting dalam upaya mengembangkan pribadi anak. Perawatan dan perhatian orang tua yang penuh dengan kasih sayang dan penanaman nilai-nilai tasawuf dalam kehidupan sehari-hari merupakan faktor yang kondusif untuk mempersiapkan anak menjadi pribadi dan anggota masyarakat yang sehat.

Pada hakikatnya tasawuf merupakan sebuah upaya melatih jiwa dengan berbagai kegiatan yang dapat membebaskan diri dari pengaruh kehidupan dunia, sehingga tercermin akhlak yang mulia dan dekat dengan Allah SWT. Dengan kata lain tasawuf adalah bidang kegiatan yang berhubungan dengan pembinaan mental rohani agar selalu dekat dengan Allah SWT.

Penanaman nilai-nilai tasawuf di dalam keluarga merupakan bentuk ajaran orang tua yang diberikan kepada anak-anaknya untuk menjadi pribadi yang baik sesuai dengan normanorma yang berlaku dalam masyarakat dan Negara, karena akan menumbuhkan sifat ihsan dalam perilaku sehari-hari sehingga merasakan kedekatan diri dengan 
sang Khaliq, dan selanjutnya akan menimbulkan kesadaran untuk melaksanakan ajaran-ajaran agama Islam dengan istiqamah.

\section{Daftar Pustaka}

A Mustofa, Akhlak Tasawuf, Bandung, Pustaka Setia, 1999.

A. Rivay Siregar, Tasawuf: Dari Sufisme Klasik ke NeoSufisme, Jakarta: Raja Grafindo, 2002.

A.Bachrun Rifa ${ }^{\text {eeI }}$ dan Hasan Mud" is, Filsafat Tasawuf, Bandung, CV Pustaka Setia, 2010.

Abdul Majid dan Dian Andayani, Pendidikan Agama Islam Berbasis Kompetensi.

Abuddin Nata, Akhlak Tasawuf, PT RajaGrafindo Persada, Jakarta, 2002.

Afifi Abdul Fatlah Thabbarah, Dosadosa Mellunli AI-Qur'all, Telj. Bahrun Abu Bakar.

Ahmad Musthafa Al-Maraghi, Tafsir Al-Maraghi, terj. Bahran Abu Bakar, dkk. Semarang, Toha Putra, 1992.

Ali Badawi, Imbalan dan Hukuman Pengaruhnya bagi Pendidikan Anak, Jakarta, Gema Insani Press, 2002.

Amin Syukur, Zuhud di Abad Modern, Yogyakarta, Pustaka Pelajar, 1997.
Departemen Agama RI, Al-Qur'an, Al-Qur'an dan Terjemahnya, Surabaya, 2004.

DEPDIKBUD, Kamus Besar Bahasa Indonesia, Jakarta, Balai Pustaka, 1990.

Djamarah, Syaiful Bahri, Pola Komunikasi Orang Tua dan Anak Dalam, Erlangga, 2012.

Faried, Ahmad, Menyucikan Jiwa : Konsep Ulama Salaf, Risalah Gusti: Surabaya, 1993.

Hamka, Tasawuf Modern, Pustaka Panjimas, Jakarta, 1990.

Hamka, Tasawuf, 3; Nurcholis Madjid, Islam Agama Peradaban: Membangun Makna dan Relevansi Islam dalam Sejarah, Jakarta, Yayasan Paramadina, 1995.

Hasan Langgulung, Jakarta:.Manusia dan Pendidikan Suatu Analisa Psikologis, Filsafat danPendidikan, Pustaka AlHusna, 2004.

Hasyim Muhammad, Dialog Antara Tasawuf dan Psikologi Keluarga, Anggota IKAPI, Jakarta , PT RINEKA CIPTA.

Hasyim Muhammad, Dialog Antara Tasawuf dan Psikologi, Yogyakarta, Pustaka. Pelajar Offset: 2002.

Hery Noer Aly, Ilmu Pendidikan Islam, Jakarta: Logos, 1999. 
M. Solihin, Rosihan Anwar, Ilmu Tasawuf, Bandung, Pustaka Setia, 2008.

M. Zain Abdullah, Dzikir dan Tasawuf, Solo, 2007.

Mahmud Yunus, Kamus Arab Indonesia, Jakarta, Hidakarya Agung, 1990.

Mantep Miharso, Pendidikan Keluarga Qur'ani, Yogyakarta: Safiria Insania Press, 2004.

Muhammad Rabbi Muhammad Jauhari, Keistimewaan Akhlak Islami, terj. Dadang Sobar Mutaman, Maqam-maqam Sufi dalam Al Qur'an, Yogyakarta, Al-Manar, 2008.

Rakhmat, Jalaluddin, Membuka Tirai Kegaiban: Renungan-Renungan Sufistik, Bandung: Mizan, 2001.

Rosihan Anwar, Akhlak Tasawuf, Bandung, Pustaka Setia, 2010 Samsul Munir Amin, Ilmu Tasawuf, Jakarta , Amzah, 2012.

Sutan Muhammad Zain, Kamus Modern Bahasa Indonesia, Jakarta, Grafika, tth.

Syaiful Bahri Djamarah, Pola Asuh Orang Tua Dan Komunikasi Dalam Keluarga: Upaya Membangun Citra membentuk Pribadi Anak, Jakarta: PT Rineka Cipta, 2014.
Syukur, Amin, Sufi Healing; Terapi dengan Metode Tasawuf, Jakarta .

TM. Hasbi Ash Shiddieqy, al-Islam. I, Pustaka Rizki Putra, Semarang, 2001.

W.J.S. Poerwadarminta, Kamus Umum Bahasa Indonesia, (Jakarta: PN Balai Pustaka, Yogyakarta, 2002. 